\title{
ANALISIS PENGARUH PEMANFAATAN PENGGUNAAN MEDIA INTERNET TERHADAP MOTIVASI BELAJAR MAHASISWA UNIVERSITAS PAMULANG TAHUN AJARAN 2019
}

\author{
NASMAL HAMDA \\ Dosen Program Studi Pendidikan Ekonomi Universitas Pamulang \\ *)email: Dosen02178@unpam.ac.id
}

\begin{abstract}
ABSTRAK
Tujuan penelitian ini adalah 1) mengetahui motivasi mahasiswa dalam melakukan kegiatan belajar dengan pemanfaatan penggunaan media internet sebagai media pendukung mahasiswa dalam belajar. Adapun dalam penelitian yang dilakukan sifatnya deskriptif dimana jumlah mahasiswa dalam penelitian ini ialah seluruh mahasiswa pendidikan ekonomi semester 4 mata kuliah ekonomi makro berjumlah 62 mahasiswa Universitas Pamulang yang terdiri dari 3 kelas yaitu kelas 04PIEP002, kelas 04PIEP001 dan kelas 04PIEM001. Data yang diambil dalam penelitian ini menggunakan angket dan dokumentasi. Adapun teknik penggunaannya menggunakan teknik analisis deskriptif dan dilanjtkan dengan analisis regresi linier sederhana. Kemudian untuk mengetahui uji kelayakan regresi menggunakan appl SPSS 22. Adapun hasil yang diperoleh dengan pemanfaatan penggunaan media internet sebagai pendukung kegiatan belajar mahasiswa mempunyai efek terhadap motivasi mahasiswa dalam belajar sebesar $46,7 \%$. Jadi dapat disimpulkan bahwa terdapat pengaruh pemanfaatan penggunaan media internet terhadap motivasi belajar mahasiswa pendidikan ekonomi semester 4 Universitas Pamulang.
\end{abstract}

\section{Kata Kunci: Motivasi belajar, Pemanfaatan penggunaan jaringan internet}

\section{PENDAHULUAN}

Begitu pesatnya perkembangan teknologi sekarang ini sudah menjadi kebutuhan manusia sehari - hari, tanpa disadari bahwa produk teknologi yang diciptakan guna mempermudah aktifitas manusia dalam kegiatan sehari - hari sudah menjadi kebutuhan manusia di
Indonesia. Penggunaan barang elektronik seperti televise, telpon, handphone sekarang ini bukan menjadi barang aneh dan baru, tidak hanya di kota - kota besar namun sudah masuk ke pelosok - pelosok desa. Mulai dari orang yang sudah tua sampai anak anakpun menggunakan media canggih 
menyesuaikan perkembangan zaman yang begitu pesat saat ini yang diciptakan oleh manusia itu sendiri.

Penggunaan media saat ini sudah mendunia terlebih lagi adanya perkembangan alat - alat canggih yang ditanamkan dalam media tersebut yaitu internet. Internet merupakan kumpulan jaringan yang dihubungkan oleh media fisik guna mengetahui informasi dan bentuk dapat di akses dan terhubung antar seluruh wilayah. Adanya internet tentunya membuka peluang manusia terhadap masa depan, adanya percakapan baru, pasar baru dan tentunya sebagai lahan bisnis yang tak ada batasnya.

Tanpa diketahui secara langsung dengan adanya internet diciptakan telah mengubah kehidupan tatap muka antar manusia, telah mengubah kehidupan masyarakat sebelumnya. Adapun perubahan tersebut dapat kita jumpai yaitu perubahan pola interaksi bisnis, ekonomi, social dan bahkan budaya di lingkungan masyarakat tersebut. Dampak internet yang begitu besar bagi rumah tangga, industri - industri, wirausaha serta pusat. Adanya alat yang dibuat ini telah menngangkat efektivitas dan kemudahan dalam kegiatan baik rumah tangga, perusahaan, pengusaha yang berwirausaha dan menjalankan bisnisnya, serta pemerintah dalam kerjasama luar negeri terutama peranannya sebagai sarana informasi, komunikasi, dan publikasi terhadap hasil daripada para pelaku perekonomian tersebut. Selain itu pemanfaatan media internet juga menjadi tempat mendapatkan berita terbaru yang sangat dibtuhkan lembaga atau lembaga usaha, industri lain yang beroperasi didalam kehidupan masyarakat.

Adanya perkembangan teknologi sekarang ini tentunya harus dimanfaatkan sebaik - baiknya yaitu dengan memanfaatkan penggunaan internet terhadap proses kegiatan pendidikan. Dalam meningkatkan mutu dan kualitas pendidikan di Indonesia tentunya dengan memanfaatkan teknologi - teknologi terbarukan guna mempermudah kekancaran dalam proses pembelajaran dan akhirnya meningkatkan output pendidikan yang lebih baik lagi dari sebelumnya. Adanya perkembangan teknologi berupa jaringan internet tentunya disambut baik oleh dunia pendidikan karena dengan adanya jaringan internet mempermudah 
transfer ilmu dalam kegiatan pembelajaran, melalui jaringan internet, ilmu dapat dengan cepat disebarluaskan, ekonomis dan tentunya handal. Adanya letak jarak yang jauh, perbedaan tempat karena letak geografis bukan menjadi kendala sesorang untuk mengetahui inforrmasi yang luas.

Begitu juga dengan mahasiswa Peko Universitas Pamulang, bahwa penggunaan internet sudah tidak menjadi hal yang tabu lagi, semua bisa mendapatkan ilmu pengetahuan yang mereka inginkan dengan memanfaatkan area hodsport yang sudah disedikan oleh kampus, dan bisa juga dengan memanfaatkan jaringan seluler berupa handphone yang berbasis android dengan mengakses pengetahuan dari tempat tinggalnya.

Berdasarkan latar belakang di atas, maka peneliti tertarik untuk melakukan penelitian guna mengetahui pemanfaatan penggunaan media jaringan internet oleh mahasiswa pendidikan ekonomi Universitas Pamulang Tangerang Selatan, apakah penggunaan media internet digunakan sebagai sumber kegiatan belaja atau hanya didgunakan sebagai hiburan semata. Tujuan dari penelitian ini adalah untuk : 1) Mengetahui faedah penggunaan media jaringan internet sebagai alat pendukung sumber belajar mahasiswa Peko Universitas Pamulang. 2) Mengetahui dampak dari pemanfaatan internet terhadap motivasi mahasiswa dalam kegiatan belajar mahasiswa Peko Universitas Pamulang. Adapun dalam hal ini menggunakan beberapa asumsi diantaranya adalah: 1)Mahasiswa pendidikan ekonomi telah mampu menggunakan media jaringan internet, 2) Keseluruhan mahasiswa Peko sudah menggunakan alat pendukung dalam kegiatan pembelajaran baik di kelas maupun mengerjakan tugas - tugas kuliah, 3) Dosen dalam kegiatan pembelajaran sudah menggunakan jaringan internet.

\section{KAJIAN TEORI}

Menurut Ahmadi dan Hermawan (2013: 68) mengatakan bahwa internet adalah komunikasi jaringan yang menyeluruh dan terhubung dengan seluruh media fisik berupa computer di dunia meskipun berbeda system operasi dan mesin yang digunakan. Ismail (2017: 58) dalam jurnal ilmiah pendidikan dan ekonomi mengatakan bahwa internet merupakan jaringan luas dari komputer, selanjut Pardosi dalam 
Ismail (2017: 58) mengatakan bahwa internet berasal dari bahasa latin "inter" yaitu antara.

Pibriana, Ricoida (2017:105) menjelaskan bahwa internet merupakan sebuah jaringan yang memungkinkan manusia untuk saling bercengkrama dengan yang lainya, menerima serta menyebarkan pesan penting.

Sutejo (2007: 51) dalam bukunya menjelaskan bahwa bila dilihat dari sejarahnya, jaringan internet sudah dirintis pada tahun 1970, namun perkembangannya baru terasa baru terjadi pada beberapa tahun terakhir. Sejak tahun 1999, mencatat bahwa lebih dari 200 juta pengguna di suluruh penjuru dan terus meningkat beriringan dengan pesatnya perkembangan teknologi.

Sedangkan perkembangan di Indonesia sendiri, internet mulai dikembangkan oleh kampus Universitas Indonesia pada tahun 1983 berupa UINET. Jaringan ini didirikan selama 4 periode lamanya dan pada tahun yang sama mulai berkembang sampai kebeberapa kampus lainnya dengan jangkauan luas yang meliputi UI, ITB, IPB, UGM ITS, Universitas Hasanudin dan Dirjen Dikti (Sutejo, 2007 : 52).
Menurut Oetomo dalam Rusno (2010: 164) menjelasakan "bahwa bagi para dosen dan mahasiswa atau pendidik dan peserta didik, internet merupakan suatu hal yang baru, sumber ilmu pengetahuan terbaru. Beberapa artikel dan bahasan menarik yang dijumpai didalam isi artikel tersebut". Selanjutnya adanya alat ini merupakan sebuah hal baru untuk memperoleh pesan berupa informasi penting, suatu alat bagi mahasiswa untuk mengembangkan potensi akademiknya.

Penggunaan jaringan internet tentu mahasiswa akan mendapatkan pengetahuan yang dia minati, baik informasi yang berada dalam negeri maupun diluar negeri.Adanya internet tersebut menajadikan kemudahan bagi mahasiswa untuk mengetahui pengetahuan yang ditampung dalam jaringan internet global dengan jutaan yang dapat menambah wawasan tentunya bagi mahasiswa Peko.

Rusno (2010: 163) dalam jurnalnya mengatakan bahwa pemanfaatan penggunaan internet terutama pada Perguruan tinggi, umumnya dipacu adanya tugas - tugas kuliah sehingga internet sangat membantu mahasiswa dalam menyelesaikan tugas tersebut. 
Selanjutnya menurut Anggraini (2016: 104) menjelaskan bahwa jika mahasiswa mampu memanfaatkan dan menguasai pembelajaran dengan baik, maka akan dipastikan mahasiswa tersebut akan lulus dengan nilai yang baik pula. Dalam hal ini bahan pembelajaran yang dimaksud dalam penelitian ini adalah dengan pemanfaatan penggunaan jaringan internet dalam proses pembelajaran.

\section{PENELITIAN TERDAHULU}

Berikut ini merupakan penelitian penelitian terdahulu yang memiliki relevansi dengan penelitian yang dilakukan diantaranya:

a.Penelitian Rusno (2010) yang berjudul "Pengaruh Penggunaan Internet Sebagai Salah Satu Sumber Belajar Terhadap Prestasi Belajar Mahasiswa Pendidikan Ekonomi Universitas Kajuruhan Malang”, populasi dalam penelitian ini adalah total mahasiswa 387, sampel yang diambil sebanyak 96 mahasiswa dengan teknik pengambilan sampel menggunakan proportional random sampling dengan menggunakan metode kuesioner. Adapun hasil dalam penelitian ini dimana didapat hasil analisis data yang signifikan terdapat $\mathrm{t}$ hitung $>\mathrm{t}$ table yang menandakan H0 ditolak, sehingga dapat disimpulkan "ada pengaruh penggunaan internet sebagai salah satu sumber belajar terhadap prestasi belajar mahasiswa pendidikan ekonomi Universitas Kanjuruhan Malang".

b. Penelitian Desi Pibriana dkk (2017) yang berjudul "Analisis Pengaruh Penggunaan Internet Terhadap Minat Belajar Mahasiswa Perguruan Tinggi di Kota Palembang", populasi dalam penelitian ini adalah seluruh mahasiswa Perguruan tinggi. Teknik pengambilan sampel menggunakan teknik random sampling dan diambil sampe sejumlah 273. Adapun metode dalam penelitian ini menggunakan metode kuesioner. Kesimpulan dari penelitian ini bahwa adanya sikap positif mahasiswa dengan adanya internet sebagai salah satu motivasi belajar untuk menumbuhkan minat mahasiswa belajar.

\section{METODE PENELITIAN}

Penelitian ini merupakan penelitian deskriptif kuantitatif dimana kerangka berfikir penelitian sebagai berikut:

\section{$\mathrm{X} \rightarrow \mathrm{Y}$}

Dimana variabel $X$ berupa jaringan internet dan variabel $\mathrm{Y}$ merupakan 
Motivasi belajar mahasiswa. Adapun maksud dari tanda panah tersebut adalah apakah ada pengaruh Variabel X terhadap Variabel Y.

Penelitian ini merupakan penelitian deskriptif kuantitatif dengan populasi dalam penelitian ini adalah seluruh mahasiwa Pendidikan Ekonomi semester 4. mata kuliah makro ekonomi Universita Pamulang tahun ajaran 2019 sebanyak 62 mahasiswa yang terdiri dari 3 kelas yaitu kelas 04PIEP002, kelas 04PIEP001 dan kelas 04PIEM001.

Adapun teknik pengumpulan data dalam penelitian ini menggunakan metode angket atau kuesioner dan metode dokumentasi. Selain itu analisi data terlebih dahulu diujikan dengan uji normalitas dan uji heteroskedastisitas dan selanjutnya baru dianalisis dengan menggunakan regresi linier sederhana

\section{HASIL DAN PEMBAHASAN}

\section{Uji Normalitas}

Penelitian ini dalam uji normalitas menggunakan SPSS didapat hasil dari uji normalitas data dapat diperoleh pendekatan grafik sebagai berikut:

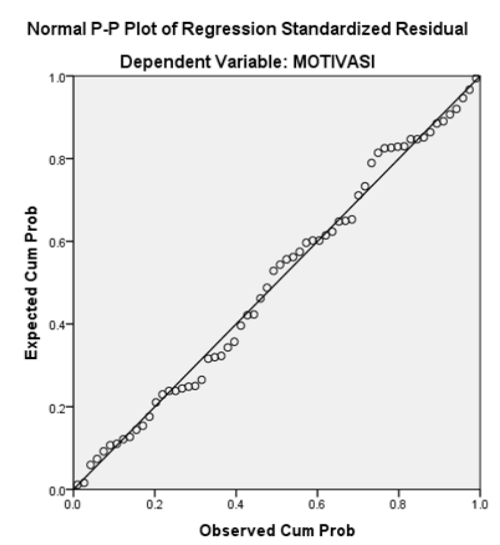

Jika dilihat dari kurva Normal P-P Plot didapat titik - titik tersebut berada di sekitar garis normal.Hal ini menandakan bahwa titik residual berasal dari data berdistribusi normal, dan pada akhirnya dapat dinyatakan bahwa regresi telah memenuhi persyaratan normalitas.

Adapun hasil uji normalitas Kolmogorov Smirnov dapat dilihat table dibawah ini:

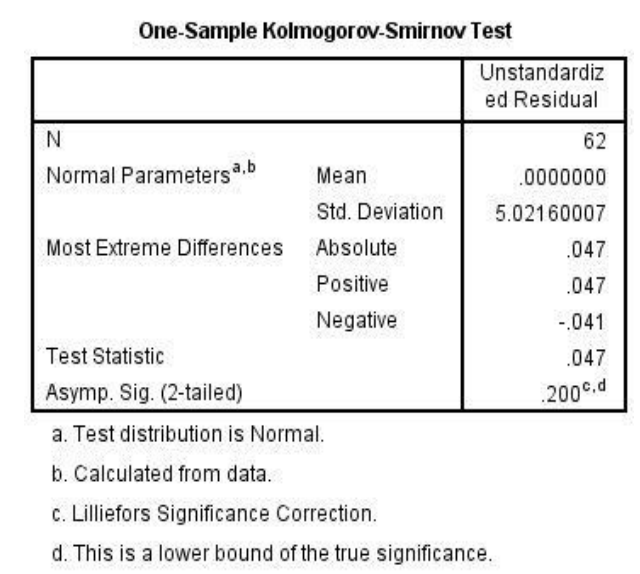

Berdasarkan tabel di atas dapat diketahui bahwa nilai signifikansinya adalah sebesar 0,200 dimana lebih besar dari 0,05 maka dapat dinyatakan bahwa nilai residual berdistribusi normal. 


\section{Uji Heteroskedastisitas}

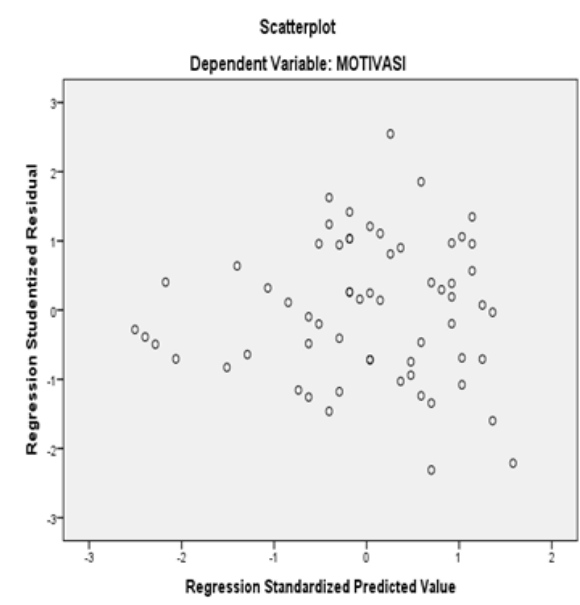

Berdasarkan grafik pada scatterplot di atas maka dapat diketahui bahwa terdapat penyebaran titik - titik baik di atas maupun dibawah disekitar angka nol, selain titik - titik tersebut tidak mengumpul hanya di atas ataupun dibawah saja dan penyebaran titik - titik tersebut tidak membentuk pola tertentu seperti pola bergelombang ataupun membentuk pola garis lurus.

Sehingga dapat disimpulkan bahwa dalam model regresi pengaruh pemanfaatan internet terhadap motivasi belajar mahasiswa tidak terjadi masalah heteroskedastisitas sehingga uji asumsi klasik ini terpenuhi dan dapat lanjut pada tahap analisis data dengan regresi linier sederhana.

\section{Uji Regresi Linier Sederhana}

\begin{tabular}{|c|c|c|c|c|}
\hline \multicolumn{5}{|c|}{ Model Summary } \\
\hline Model & $\mathrm{R}$ & R Square & $\begin{array}{l}\text { Adjusted } \\
\text { R Square }\end{array}$ & $\begin{array}{l}\text { Std. } \\
\text { Error of } \\
\text { the } \\
\text { Estimate }\end{array}$ \\
\hline 1 & .684 & .467 & .459 & 5.22983 \\
\hline
\end{tabular}

Berdasarkan tabel di atas dapat dilihat bahwa besarnya nilai korelasi/hubungan $\mathrm{R}$ yaitu 0,684 . Sehingga dapat dikatakan hubungan antara variable $\mathrm{X}$ terhadap variable $\mathrm{Y}$ dengan total hubungannya sebesar 0,684 .

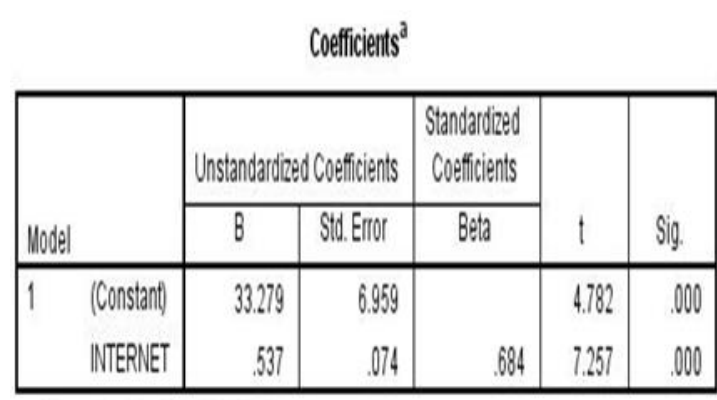

a. DependentiVariable: MOTNAS|

Untuk mengetahui pengaruh adanya pemanfaatan internet terhadap motivasi belajar mahasiswa dengan menggunakan cara jika sig > 0,05 maka $\mathrm{H} 0$ diterima dan sebaliknya jika $\mathrm{H} 0<$ 0,05 maka H0 ditolak. Dari output koefisien table di atas dapat diketahui bahwa terdapat nilai konstanta sebesar 33,279 yang megandung arti bahwa nilai konsisten variable pertispasinya sebesar 33,279. Sedangkan untuk nilai 
$t_{\text {hitung }}$ diperoleh sebesar $7,257>t_{\text {tabel }}$ 2,000 atau sig $\mathrm{t}<0,05$ yaitu $0,00<0,05$ yang artinya H0 ditolak. Sehingga dapat diartikan bahwa Ha berbunyi "Ada pengaruh pemanfaatan penggunaan internet terhadap motivasi belajar mahasiswa pendidikan ekonomi Universitas Pamulang."

Adapun pemanfaatan internet $(\mathrm{X})$ berdampak porsitif yang diperoleh terhadap motivasi belajar mahasiswa (Y) pada Universitas Pamulang.

\section{PEMBAHASAN}

Berdasarkan hasil perhitungan diperoleh bahwa pemanfaatan internet mempunyai dampak yang positif terhadap motivasi mahasiswa dalam kegiatan belajar di Universitas Pamulang, hasil yang dapat dilihat dari R Square sebesar 46,7\%.

Sehingga dapat disimpulkan bahwa pemanfaatan penggunaan internet berdampak positif terhadap pengaruh motivasi belajar mahasiswa itu sendiri, namun perlu adanya pengawasan dan batasan dalam penggunaan internet tersebut.

\section{KESIMPULAN DAN SARAN}

\section{Kesimpulan}

Adapun kesimpulan dalam penelitian ini sebagai berikut:
1. Mahasiswa Pendidikan Ekonomi pada mata kuliah ekonomi makro telah memanfaatkan penggunaan jaringan internet sebagai media yang efektif dan efisien dalam pembelajaran mandiri.

2. Terdapat adanya pengaruh pemanfaatan penggunaan jaringan internet sebagai sumber bekajar pendukung mahasiswa terhadap motivasi belajar mahasiswa Pendidikan Ekonomi Universitas Pamulang.

\section{Saran}

Adapun saran dalam penelitian ini adalah sebagai berikut:

1. Penelitian ini menyimpulkan bahwa terdapat pengaruh pemanfaatan penggunaan jaringan internet terhadap motivasi belajar mahasiswa Pendidikan Ekonomi. Oleh karena itu pemanfaatan penggunaan jaringan internet dalam kegiatan pembelajaran di Universitas Pamulang sebagai media belajar yang hendaknya perlu ditingkatkan sehingga nantinya peningkatan motivasi belajar akan meningkat dan menghasilkan output pembelajaran yang baik pula.

2. Univesitas Pamulang diharapkan perlu adanya perbaikan fasilitas penyediaan jaringan internet dari segi 
kecepatan jaringan internet sehingga dapat dengan mudah dilakukan oleh seluruh mahasiswa.

3. Penggunaan internet tentunya perlu ada batasan - batasan dalam penggunaan jaringan internet baik sebagai media pembelajaran maupun sebagi media hiburan. Selama ini banyak kasus internet disalahgunakan bagi penggunanya sebagai media yang dapat melanggar hukum.

\section{DAFTAR PUSTAKA}

Ahmadi dan Hermawan, 2013. E Bussines \& $E-$ Comerce. Yogyakarta: Andi.

Anggraini, Irma Susi, 2016. Motivasi Belajar dan Faktor - Faktor yang Berpengaruh: Sebuah Kajian Pada Interaksi Pembelajaran Mahasiswa: E Journal PGSD IKIP PGRI Madiun

Ismail, Khafid, 2017. Pengaruh Penggunaan Internet Terhadap Hasil Belajar Ilmu Pengetahuan Sosial Peserta Didik Kelas X SMK Nurul Huda Sukaraja Oku Timur. Jurnal Ilmiah Pendidikan dan Ekonomi Volume 1 Nomor 1

Pibriana, Desi dkk, 2017. Analisis Pengaruh Penggunaan Internet Terhadap Minat Belajar Mahasiswa Perguruan Tinggi di Kota Palembang.: Jurnal Jatisi Volume

Rusno, 2010. Pengaruh Penggunaan Internet Sebagai Salah Satu Sumber Belajar Terhadap Prestasi Belajar Mahasiswa Pendidikan Ekonomi
Universitas Kajuruhan Malang: Jurnal Ekonomi Modernisasi Fakultas Ekonomi Volume 6 Nomor 2.

Sutejo, Dharma Oetomo, Budi, 2007. Pengantar Teknologi Informasi Internet: Konsep dan Aplikasi, Yogyakarta: Andi Offset. 